\title{
PERILAKU DANA PIHAK KETIGA DALAM MERESPON PERUBAHAN VARIABEL EKONOMI MAKRO PADA BANK UMUM SWASTA NASIONAL (BUSN) PROVINSI JAWA TIMUR PERIODE 2000-2012
}

Oleh:

\author{
Dhurotus Sangadah
}

\begin{abstract}
The purpose of this reserach is to knowing of responbility of dependent variabel to exchange of makro economics variable at Excahage Commercial Bank province of East Java. The model analysis is Doubled Linear Regression with employs the OLS (Ordinary Least Square) method. In this research will be used four regression with four dependent variables. In the equation model Saving Deposits, Demand Deposits, Tme Deposits, Third Party Funds are dependent variables and per capita income, interest rate, inflation are independent variables. Result of regression was showed that Saving Deposit more sensitive to respon change of inflations variable that showed by its probability is 0,0024. Time deposit moere sensitive to respon change of interest rates variable taht showed by its probability was 0,0012. Per capita income has same respon of all dependent variable that swowed by its probability was 0,0000
\end{abstract}

Keywords : Third Party Funds, Per Capita income, Interest Rates, Inflation

\begin{abstract}
ABSTRAK
Tujuan penelitian ini adalah untuk mengetahui respon yang ditunjukkan oleh variabel dependent (Tabungan, Giro, Deposito, Dana Pihak Ketiga) terhadap perubahan variabel ekonomi makro pada Bank Umum Swasta Nasional Provinsi Jawa Timur. Alat analisis yang dugunakan adalah Regresi Linear Berganda dengan model estimasi metode Kuadrat Terkecil. Dalam persamaan model, Tabungan, Giro, Deposito, Dana Pihak Ketiga adalah variabel terikat dan pendapatan per kapita, suku bunga, inflasi adalah variabel bebas. Berdasarkan hasil regresi diketahui bahwa Tabungan lebih sensitif dalam merespon perubahan inflasi yang ditunjukkan dengan probabilitas sebesar 0,0024 sedangkan Deposito lebih sensitif dalam merespon perubahan variabel suku bunga yang ditunjukkan oleh probabilitas suku bunga pada regresi Deposito sebesar 0,012. Variabel pendapatan per kapita direspon secara rata oleh variabel dependent yang ditunjukkan oleh probabilitas pendapatan per kapita pada semua regresi sebesar 0,0000
\end{abstract}

Kata kunci : Dana Pihak Ketiga, Pendapatan Per Kapita, Suku Bunga, Inflasi 


\section{PENDAHULUAN}

Berdasarkan Pancasila dan Undang-Undang Dasar 1945, tujuan pembangunan nasional adalah untuk mewujudkan suatu masyarakat yang adil dan makmur, sehingga untuk mencapai tujuan pembangunan tersebut diperlukan adanya partisipasi dari berbagai pihak.

Perbankan sebagai lembaga keuangan yang dianggap mampu mendukung pembangunan yang sedang digalakkan oleh pemerintah, yaitu dengan menjalankan fungsinya sebagai lembaga intermediasi maka bank dapat membantu sektor riil dalam perekonomian untuk meningkatkan tingkat output sehingga dapat membantu meningkatkan pertumbuhan perekonomian, oleh karena itu kemajuan Perbankan pada suatu negara dapat dijadikan sebagai ukuran bagi kemajuan negara tersebut. Menurut Kasmir (2011), Semakin maju suatu negara maka semakin besar pula peranan perbankan dalam perekonomian negara tersebut.

Pada dasarnya sumber dana bank memiliki fungsi yang berbeda- beda, untuk penyaluran kredit bank akan menggunakan dana yang berasal dari masyarakat atau yang sering kita kenal Dana Pihak Ketiga. Jadi secara tidak langsung besarnya kredit yang disalurkan kepada masyarakat dipengaruhi oleh Dana Pihak Ketiga yang dimiliki oleh Bank yang bersangkutan. Semakin besar Dana Pihak Ketiga yang dihimpun oleh Bank maka semakin besar pula kredit yang dapat disalurkan oleh bank. Tidak mengherankan jika ada sebagai orang yang menganggap bahwa keberhasilan suatu Bank dapat dilihat dari besarnya Dana Pihak Ketiga yang dapat dihimpun.

Penghimpunan dana dari masyarakat dapat dikatakan relatif lebih mudah jika dibandingkan dengan sumber dana lainnya. Penghimpunan dana dari masyarakat dapat dilakukan secara efektif dengan memberikan bunga yang relatif lebih tinggi dan memberikan berbagai fasilitas yang menarik lainnya seperti hadiah dan pelayanan yang memuaskan. 
Keuntungan lain dari dana yang bersumber dari masyarakat adalah jumlahnya yang tidak terbatas baik berasal dari perseorangan, perusahaan maupun lembaga masyarakat lainnya. Jika dibandingkan Dana Pihak Kedua (dana pinjaman Bank lain dan lainlain), Dana Pihak Ketiga termasuk dana murah karena biaya perolehan Dana Pihak Ketiga relatif lebih murah.

Produk Dana Pihak Ketiga memiliki karakteristik yang berbedabeda hal ini menyebabkanDana Pihak Ketiga memiliki perilaku yang berbeda dalam merespon perubahan variabel makro (pendapatan per kapita, suku bunga dan Inflasi). Simpanan Giro memiliki labilitas Dana yang tinggi sehingga respon Giro terhadap perubahan variabel suku bunga dan Inflasi akan berbeda dengan respon yang ditunjukkan oleh Tabungan dan Deposito.

Neny (2007) melakukan
penelitian pada bank umum di
Pemantang Siantar-Simalungun
tentang "analisis faktor-faktor yang
mempengaruhi jumlah simpanan
masyarakat pada Bank-Bank Umum

di Pemantang Siantar" Simalungun. Dari hasil penelitian tersebut diketahui bahwa pendapatan per kapita, suku bunga dan inflasi berpengaruh terhadap jumlah simpanan masyarakat. Fatmawati (2007) melakukan penelitian terhadap penghimpunan dana masyarakat di Jawa Timur dengan judul "Analisis faktor-faktor yang mempengaruhi penghimpunan dana masyarakat pada Bank Umum di wilayah Jawa Timur".dari penelitian tersebut diketahui bahwa variabel pendapatan per kapita dan suku bunga berpengaruh terhadap jumlah dana pihak ketiga.

\section{METODE PENELITIAN}

Objek penelitian yang dipilih oleh peneliti adalah Bank Umum Swasta Nasional yang beroperasi di Provinsi Jawa Timur. Pemilihan wilayah obyek penelitian didasarkan pada pertimbangan bahwa Jawa Timur merupakan Provinsi yang mempunyai pertumbuhan ekonomi yang cukup tinggi jika dibanding dengan pertumbuhan ekonomi di Indonesia. Berdasarkan data dari Badan Pusat 
Statistik Jawa Timur (2011),

diketahui rata-rat pertumbuhan ekonomi di Jawa Timur tahun 20012011 sebesar $\quad 3,50 \%$ sedangkan Nasional sebesar 3,32\%.

Penelitian ini bersifat deskriptif kuantitatif, yaitu penelitian yang sifatnya memberikan gambaran sistimatis secara umum berdasarkan data atau angka yang ada kemudian dianalisis dan diinterprestasikan dalam bentuk uraian. Jika dari sumber perolehannya Data yang akan dianalisis dalam penelitian ini adalah data sekunder yaitu data yang telah dikumpulkan oleh pihak lain atau dengan kata lain data yang diperoleh dalam bentuk sudah jadi, sudah dikumpulkan dan diolah oleh pihak lain biasanya sudah dalam bentuk publikasi.

Berdasarkan bentuk penyusunannya data yang digunakan adalah data tahunan (time series). Data yang digunakan dalam penelitian ini adalah Data perkembangan Dana Pihak Ketiga periode 2000-2012, Data tingkat suku bunga Dana Pihak Ketiga pada Bank Umum Swasta Nasional periode 2000-2012, Data Pendapatan
Regional Bruto Provinsi Jawa Timur periode 2000-2012, Data Jumlah penduduk Provinsi Jawa Timur periode 2000-2012, Data tingkat Inflasi Provinsi Jawa Timur periode 2000-2012. Data ini diperoleh melalui Bank Indonesia dan Badan Pusat Statistik Provinsi Jawa Timur.

Dalam pengumpulan data, peneliti menggunakan teknik dokumentasi, yaitu teknik pengumpulan informasi dengan cara mencatat data-data yang telah dipublikasikan oleh lembaga atau instansi terkait, seperti laporan keuangan, makalah dan dokumendokumen yang berkaitan dengan penelitian.

Teknik analisis yang digunakan adalah Regresi Linear Berganda. Regresi linear Berganda adalah suatu studi yang meneliti mengenai ketergantungan satu variabel dependent terhadap satu atau lebih variabel lainnya yaitu variabel independent yang bertujuan untuk mengestimasi dan atau memperkirakan nilai rerata (populasi) variabel dependent dari nilai yang diketahui atau nilai tetap dari variabel independent. Metode 
estimasi yang digunakan adalah metode kuadrat terkecil biasa (Ordinary Least Square), yaitu suatu metode estimasi yang dilakukan dengan cara memperkecil kesalahan penaksiran dengan cara menderivasi jumlah kuadrat kesalahan terhadap nilai penaksir parameter hingga nol.

Untuk menganalisis dan menguji data dalam penelitian, peneliti menggunakan uji statistik dan uji ekonometrika. Uji statistik yang digunakan adalah pengujian hipotesis, antara lain uji " $t$ ", uji” F" dan Determinasi Koefisien. Sedangkan uji ekonometrika yang digunakan untuk menguji penyimpangan asumsi klasik antara lain uji Heterokedastisitas, uji Autokorelasi dan uji Multikolinearitas.

\section{PEMBAHASAN}

Data-data diproses dengan menggunakan eviews 4.0 for windows. Analisis digunakan untuk melihat pengaruh masing-masing variabel independent, yaitu pendapatan per kapita, suku bunga, inflasi terhadap variabel dependent, yaitu Tabungan, giro, deposito, dana pihak ketiga.

Pertama, Persamaan regresi Tabungan adalah $\mathrm{LY}_{1}$ : $-9,725875+$ $3.349202 \mathrm{LX}_{1}+0.025584 \mathrm{X}_{2}-$ $0.012835 X_{3} . \alpha:-9,725875$ adalah konstanta yang berarti besarnya jumlah Tabungan $\left(\mathrm{LY}_{1}\right)$ sebesar 9,725875 pada saat pendapatan perkapita $\left(\mathrm{LX}_{1}\right)$, suku bunga $\left(\mathrm{X}_{2}\right)$ dan inflasi $\left(\mathrm{X}_{3}\right)$ adalah nol/konstan.

$\beta_{1}: 3.349202 \quad$ adalah besarnya koefisien regresi untuk pendapatan per kapita $\left(\mathrm{LX}_{1}\right)$ sebesar 3.349202, hal ini menunjukkan pengaruh positif antara pendapatan perkapita $\left(\mathrm{LX}_{1}\right)$ terhadap jumlah Tabungan sebesar $3.349202 \%$. Kondisi ini menunjukkan setiap kenaikan pendapatan per kapita sebesar $1 \%$ maka jumlah Tabungan akan naik sebesar $3.349202 \%$ dengan asumsi variabel yang lain dianggap tetap.

$\beta_{2}: 0.025584$ adalah besarnya koefisien regresi untuk suku bunga $\left(\mathrm{X}_{2}\right)$ sebesar 0.025584, hal ini menunjukkan pengaruh positif antara suku bunga $\left(\mathrm{X}_{2}\right)$ terhadap jumlah Tabungan sebesar 0.025584 $\%$. Kondisi ini menunjukkan setiap 
kenaikan suku bunga sebesar $1 \%$ maka jumlah Tabungan akan naik sebesar $0.025584 \%$ dengan asumsi variabel yang lain dianggap tetap.

$\beta_{3}:-0.012835 \quad$ adalah besarnya koefisien regresi untuk inflasi $\left(\mathrm{X}_{3}\right)$ sebesar -0.012835 , hal ini menunjukkan pengaruh negatif antara suku bunga $\left(\mathrm{X}_{3}\right)$ terhadap jumlah Tabungan sebesar -0.012835 $\%$. Kondisi ini menunjukkan setiap kenaikan inflasi sebesar 1\% maka jumlah Tabungan akan turun sebesar $0.012835 \%$ dengan asumsi variabel yang lain dianggap tetap

Dari hasil uji regresi variabel diperoleh bahwa t-statistik untuk masing-masing variabel adalah : $\mathrm{LX}_{1}$ (18.75348), $\mathrm{X}_{2}(2.582566), \mathrm{X}_{3}$ (-4.160828) berpengaruh secara parsial pada tingkat signifikasi 5\% dengan df :n-k-1=13-3-1=9 : dengan nilai t- tabel sebesar $\pm 2,262$

Dari hasil regresi, diperoleh F-statistik sebesar 523.1511, sedangkan pada signifikansi $5 \%$ dan df $(3,9)$ diperoleh F-tabel sebesar 3,86. Hal ini dapat disimpulkan bahwa F-statistik (523.1511) > Ftabel $(3,86)$, berarti menolak $\mathrm{H}_{0}$. Artinya, Pendapatan per kapita $\left(\mathrm{X}_{1}\right)$, suku bunga $\left(\mathrm{X}_{2}\right)$, Inflasi $\left(\mathrm{X}_{3}\right)$ dan secara bersama-sama mempengaruhi Jumlah Tabungan (LY).

Adapun koefisien determinasi dari Regresi Tabungan sebesar 0.994298. Hal ini hal ini menunjukkan bahwa variabel independent yang terdiri dari pendapatan per kapita $\left(\mathrm{LX}_{1}\right)$, suku bunga $\left(\mathrm{X}_{2}\right)$ dan inflasi $\left(\mathrm{X}_{3}\right)$ dalam menjelaskan perubahan variabel dependent/Tabungan sebesar 99,43 $\%$ sedangkan sisanya sebesar $0,57 \%$ dijelaskan oleh variabel lain yang tidak dimasukkan dalam model estimasi.

Hasil penelitian uji heterokedastisitas dilakukan dengan menggunakan metode uji white. Dari hasil penelitian tersebut dapat disimpulkan bahwa Probability $(0,722215)>0,05$, artinya tidak terjadi heterokedastisitas.

Hasil pengolahan uji autokorelasi diperoleh nilai statistik Durbin-Watson $(\mathrm{DW})=2.462828$ pada tingkat kekeliruan $1 \%$ untuk jumlah variabel bebas $(\mathrm{k}-1)=3$ dan jumlah pengamatan $(\mathrm{n})=13$ diperoleh batas bawah nilai tabel $\mathrm{dl}=$ 0,499 dan batas atasnya $\mathrm{du}=1,526$ 
dengan nilai 4-du : 2,474 dan nilai 4dl :3,501. Nilai Durbin-Watson model regresi (2.462828) berada diantara $d u=1,526$ dan 4-du $=2,474$ maka berada di tidak terjadi autokorelasi. Dengan demikian dapat disimpulkan bahwa hasil regresi variabel Pendapatan per kapita, suku bungan, inflasi terhadap Tabungan tidak terjadi autokorelasi atau $\rho=0$.

Dengan membandingkan $\mathrm{R}^{2}$ dari regresi Tabungan dan regresi anatar variabel bebas maka doperoleh hasil adalah $\mathrm{R}_{1}^{2}(0,994)>$ $\mathrm{R}_{11}^{2} \quad(0,806), \quad \mathrm{R}_{12}^{2} \quad(0,893), \quad \mathrm{R}_{13}^{2}$ $(0,689)$ sehingga dapat disimpulkan bahwa dalam model regresi diatas tidak terjadi multikolinearitas.

Kedua, Persamaan regresi Giro adalah $\mathrm{LY}_{2}$ : $\quad-4.457793+$ $2.515585 \mathrm{LX}_{1}+0.035887 \mathrm{X}_{2}-$ $0.010305 X_{3} \alpha:-4.457793$ adalah konstanta yang berarti besarnya jumlah Giro $\left(\mathrm{LY}_{2}\right)$ sebesar 4.457793 pada saat pendapatan perkapita $\left(\mathrm{LX}_{1}\right)$, suku bunga $\left(\mathrm{X}_{2}\right)$ dan inflasi $\left(\mathrm{X}_{3}\right)$ adalah nol/konstan. $\beta_{1}$ : 2.515585 adalah besarnya koefisien regresi untuk pendapatan per kapita $\left(\mathrm{LX}_{1}\right)$ sebesar 2.515585 hal ini menunjukkan pengaruh positif antara pendapatan perkapita $\left(\mathrm{LX}_{1}\right)$ terhadap jumlah Giro $2.515585 \%$. Kondisi ini menunjukkan setiap kenaikan pendapatan per kapita sebesar 1\% maka jumlah Giro akan naik sebesar $2.515585 \%$ dengan asumsi variabel yang lain dianggap tetap.

$$
\beta_{2}: 0.035887 \text { adalah }
$$
besarnya koefisien regresi untuk suku bunga $\left(\mathrm{X}_{2}\right)$ sebesar 0.035887, hal ini menunjukkan pengaruh positif antara suku bunga $\left(\mathrm{X}_{2}\right)$ terhadap jumlah Giro sebesar $0.035887 \%$. Kondisi ini menunjukkan setiap kenaikan suku bunga sebesar $1 \%$ maka jumlah Tabungan akan naik sebesar $0.035887 \%$ dengan asumsi variabel yang lain dianggap tetap.

$$
\beta_{3}:-0.010305 \text { adalah }
$$
besarnya koefisien regresi untuk inflasi $\left(\mathrm{X}_{3}\right)$ sebesar -0.010305 , hal ini menunjukkan pengaruh negatif antara suku bunga $\left(\mathrm{X}_{3}\right)$ terhadap jumlah Giro sebesar -0.010305\%. Kondisi ini menunjukkan setiap kenaikan inflasi sebesar $1 \%$ maka jumlah Giro akan turun sebesar $0.010305 \%$ dengan asumsi variabel yang lain dianggap tetap. 
Dari hasil uji regresi variabel diperoleh bahwa t-statistik untuk masing-masing variabel adalah : $\mathrm{LX}_{1}$ (20.18083), $\mathrm{X}_{2}$ (2.266494), $\mathrm{X}_{3}$ (-3.160101) berpengaruh secara parsial pada tingkat signifikasi 5\% dengan df : n-k-1=13-3-1=9 : dengan nilai t- tabel sebesar $\pm 2,262$.

Dari hasil regresi, diperoleh F-statistik sebesar 523.1511, sedangkan pada signifikansi 5\% dan df $(3,9)$ diperoleh F-tabel sebesar 3,86. Hal ini dapat disimpulkan bahwa F-statistik (198.1342) > Ftabel $(3,86)$, berarti menolak $\mathrm{H}_{0}$. Artinya, Pendapatan per kapita $\left(\mathrm{X}_{1}\right)$, suku bunga $\left(\mathrm{X}_{2}\right)$, Inflasi $\left(\mathrm{X}_{3}\right)$ dan secara bersama-sama mempengaruhi Jumlah Tabungan (LY).

Adapun koefisien

determinasi dari Regresi giro sebesar 0.985085. Hal ini menunjukkan bahwa variabel independent yang terdiri dari pendapatan per kapita $\left(\mathrm{LX}_{1}\right)$, suku bunga $\left(\mathrm{X}_{2}\right)$ dan inflasi $\left(\mathrm{X}_{3}\right)$ dalam menjelaskan perubahan variabel dependent/Tabungan sebesar $99,51 \%$ sedangkan sisanya sebesar $1,49 \%$ dijelaskan oleh variabel lain yang tidak dimasukkan dalam model estimasi.
Hasil penelitian uji heterokedastisitas dilakukan dengan menggunakan metode uji white. Dari hasil penelitian tersebut dapat disimpulkan bahwa Probability $(0,349168)>0,05$ artinya tidak terjadi heterokedastisitas.

Hasil pengolahan uji autokorelasi diperoleh nilai statistik Durbin-Watson $(\mathrm{DW})=1,561828$ pada tingkat kekeliruan $1 \%$ untuk jumlah variabel bebas $(k-1)=3$ dan jumlah pengamatan $(\mathrm{n})=13$ diperoleh batas bawah nilai tabel $\mathrm{dl}=$ 0,499 dan batas atasnya $\mathrm{du}=1,526$ dengan nilai 4-du : 2,474 dan nilai 4dl :3,501. Nilai Durbin-Watson model regresi $(1,561828)$ berada diantara du $=1,526$ dan 4-du $=2,474$ maka berada di tidak terjadi autokorelasi. Dengan demikian dapat disimpulkan bahwa hasil regresi variabel Pendapatan per kapita, suku bungan, inflasi terhadap Tabungan tidak terjadi autokorelasi atau $\rho=0$.

Dengan membandingkan $\mathrm{R}^{2}$ dari regresi Tabungan dan regresi anatar variabel bebas maka doperoleh hasil adalah $\mathrm{R}_{1}^{2}(0,985)>$ $\mathrm{R}_{11}^{2} \quad(0,256), \quad \mathrm{R}_{12}^{2} \quad(0,457), \quad \mathrm{R}_{13}^{2}$ $(0,480)$ sehingga dapat disimpulkan 
bahwa dalam model regresi diatas tidak terjadi multikolinearitas.

Ketiga, Persamaan regresi Deposito adalah $\mathrm{LY}_{3}=-5.586837+$ $2.753520 \mathrm{LX}_{1}+0.019555 \mathrm{X} 2-$ $0.006401 \quad X_{3} . \quad \alpha \quad: \quad-5.535372102$ adalah konstanta yang berarti besarnya jumlah Deposito $\left(\mathrm{LY}_{3}\right)$ sebesar -5.535372102 pada saat pendapatan perkapita $\left(\mathrm{LX}_{1}\right)$, suku bunga $\left(\mathrm{X}_{2}\right)$ dan inflasi $\left(\mathrm{X}_{3}\right)$ adalah nol/konstan. $\beta_{1}: 2.753520$ adalah besarnya koefisien regresi untuk pendapatan per kapita (LX1) sebesar 2.753520, hal ini menunjukkan pengaruh positif antara pendapatan perkapita (LX1) terhadap jumlah Deposito sebesar $2.753520 \%$. Kondisi ini menunjukkan setiap kenaikan pendapatan per kapita sebesar 1\% maka jumlah Deposito akan naik sebesar $2.753520 \%$ dengan asumsi variabel yang lain dianggap tetap.

$\beta_{2}: 0.019555$ adalah besarnya koefisien regresi untuk suku bunga $\left(\mathrm{X}_{2}\right)$ sebesar 0.019555, hal ini menunjukkan pengaruh positif antara suku bunga $\left(\mathrm{X}_{2}\right)$ terhadap jumlah Tabungan sebesar 0.019555 $\%$. Kondisi ini menunjukkan setiap kenaikan suku bunga sebesar 1\% maka jumlah Tabungan akan naik sebesar $0.019555 \%$ dengan asumsi variabel yang lain dianggap tetap.

$\beta_{3}:-0.006401$ adalah besarnya koefisien regresi untuk inflasi $\left(\mathrm{X}_{3}\right)$ sebesar -0.006401 , hal ini menunjukkan pengaruh negatif antara suku bunga $\left(\mathrm{X}_{3}\right)$ terhadap jumlah Deposito sebesar 0.006401 $\%$. Kondisi ini menunjukkan setiap kenaikan inflasi sebesar 1\% maka jumlah Tabungan akan turun sebesar $0.006401 \%$ dengan asumsi variabel yang lain dianggap tetap.

Dari hasil uji regresi variabel diperoleh bahwa t-statistik untuk masing-masing variabel adalah: $\mathrm{LX}_{1} \quad$ (43.27502), $\quad \mathrm{X}_{2}$ (4.626454), $\quad X_{3} \quad(-2.305913)$ berpengaruh secara parsial pada tingkat signifikasi 5\% dengan df :n$\mathrm{k}-1=13-3-1=9$ : dengan nilai $\mathrm{t}-$ tabel sebesar $\pm 2,262$

Dari hasil regresi diatas, diperoleh F-statistik sebesar 1008.802, sedangkan pada signifikansi $5 \%$ dan df $(3,9)$ diperoleh F-tabel sebesar 3,86. Hal ini dapat disimpulkan bahwa Fstatistik $(1008.802)>$ F-tabel $(3,86)$, 
berarti menolak $\mathrm{H}_{0}$ Artinya, Pendapatan per kapita $\left(\mathrm{X}_{1}\right)$, suku bunga $\left(\mathrm{X}_{2}\right)$, Inflasi $\left(\mathrm{X}_{3}\right)$ dan secara bersama-sama mempengaruhi Jumlah Tabungan (LY).

Adapun koefisien determinasi dari Regresi Tabungan sebesar 0.997035. Hal ini hal ini menunjukkan bahwa variabel independent yang terdiri dari pendapatan per kapita $\left(\mathrm{LX}_{1}\right)$, suku bunga $\left(\mathrm{X}_{2}\right)$ dan inflasi $\left(\mathrm{X}_{3}\right)$ dalam menjelaskan perubahan variabel dependent/Tabungan sebesar 99,70 $\%$ sedangkan sisanya sebesar $0,30 \%$ dijelaskan oleh variabel lain yang tidak dimasukkan dalam model estimasi.

Hasil penelitian uji heterokedastisitas dilakukan dengan menggunakan metode uji white. Dari hasil penelitian tersebut dapat disimpulkan bahwa Probability $(0,932746)>0,05$, artinya tidak terjadi heterokedastisitas.

Hasil pengolahan uji autokorelasi diperoleh nilai statistik Durbin-Watson $(\mathrm{DW})=2,178158$ pada tingkat kekeliruan $1 \%$ untuk jumlah variabel bebas $(\mathrm{k}-1)=3$ dan jumlah pengamatan $(\mathrm{n})=13$ diperoleh batas bawah nilai tabel $\mathrm{dl}=$ 0,499 dan batas atasnya du $=1,526$ dengan nilai 4-du : 2,474 dan nilai 4dl :3,50. Nilai Durbin-Watson model regresi $(2,178158)$ berada diantara $d u$ $=1,526$ dan 4-du = 2,474 maka berada di tidak terjadi autokorelasi. Dengan demikian dapat disimpulkan bahwa hasil regresi variabel Pendapatan per kapita, suku bungan, inflasi terhadap Tabungan tidak terjadi autokorelasi atau $\rho=0$.

Dengan membandingkan $\mathrm{R}^{2}$ dari regresi Tabungan dan regresi anatar variabel bebas maka doperoleh hasil adalah $\mathrm{R}^{2}{ }_{1}(0,997)>$ $\mathrm{R}^{2}{ }_{11} \quad(0,4976), \quad \mathrm{R}^{2}{ }_{12} \quad(0,9034), \quad \mathrm{R}^{2}{ }_{13}$ $(0,8735)$ sehingga dapat disimpulkan bahwa dalam model regresi diatas tidak terjadi multikolinearitas.

Keempat, Persamaan regresi Tabungan adalah $\mathrm{LY}_{4}=-5.301868+$ $2.767983 \mathrm{LX}_{1}+0.014246 \mathrm{X}_{2}-$ $0.005053 \mathrm{X}_{3} . \quad \alpha:-5.301868$ adalah konstanta, yang berarti besarnya jumlah Dana Pihak Ketiga $\left(\mathrm{LY}_{4}\right)$ sebesar -5.301868 pada saat pendapatan perkapita $\left(\mathrm{LX}_{1}\right)$, suku bunga $\left(\mathrm{X}_{2}\right)$ dan inflasi $\left(\mathrm{X}_{3}\right)$ adalah nol/konstan. $\beta_{1}: 2.767983$ adalah besarnya koefisien regresi untuk 
pendapatan per kapita $\left(\mathrm{LX}_{1}\right)$ sebesar 2.769383, hal ini menunjukkan pengaruh positif antara pendapatan perkapita $\left(\mathrm{LX}_{1}\right)$ terhadap jumlah Dana Pihak Ketiga sebesar 2.769383 $\%$. Kondisi ini menunjukkan setiap kenaikan pendapatan per kapita sebesar 1\% maka jumlah Dana Pihak Ketiga akan naik sebesar 2.769383 $\%$ dengan asumsi variabel yang lain dianggap tetap.

$$
\beta_{2}: 0.014246 \text { adalah }
$$
besarnya koefisien regresi untuk suku bunga $\left(\mathrm{X}_{2}\right)$ sebesar 0.014246, hal ini menunjukkan pengaruh positif antara suku bunga $\left(\mathrm{X}_{2}\right)$ terhadap jumlah Dana Pihak Ketiga sebesar $0.014246 \%$. Kondisi ini menunjukkan setiap kenaikan suku bunga sebesar $1 \%$ maka jumlah Tabungan akan naik sebesar $0.014246 \%$ dengan asumsi variabel yang lain dianggap tetap.

$$
\beta_{3}:-0.005053 \text { adalah }
$$

besarnya koefisien regresi untuk inflasi $\left(\mathrm{X}_{3}\right)$ sebesar -0.005053 , hal ini menunjukkan pengaruh negatif antara suku bunga $\left(\mathrm{X}_{3}\right)$ terhadap jumlah Dana Pihak Ketiga sebesar $0.005053 \%$. Kondisi ini menunjukkan setiap kenaikan inflasi sebesar 1\% maka jumlah Dana Pihak Ketiga akan turun sebesar $0.005053 \%$ dengan asumsi variabel yang lain dianggap tetap.

Dari hasil uji regresi variabel diperoleh bahwa t-statistik untuk masing-masing variabel adalah: LX $_{1} \quad$ (44.08811), $\quad \mathrm{X}_{2}$ (2.393334), $\quad X_{3} \quad(-2.455008)$ berpengaruh secara parsial pada tingkat signifikasi 5\% dengan df :n$\mathrm{k}-1=13-3-1=9$ : dengan nilai $\mathrm{t}-$ tabel sebesar $\pm 2,262$.

Dari hasil regresi diatas, diperoleh F-statistik sebesar 2368.082, sedangkan pada signifikansi $5 \%$ dan df $(3,9)$ diperoleh F-tabel sebesar 3,86. Hal ini dapat disimpulkan bahwa Fstatistik $(2368.082)>$ F-tabel $(3,86)$, berarti menolak $\mathrm{H}_{0}$. Artinya, Pendapatan per kapita $\left(\mathrm{X}_{1}\right)$, suku bunga $\left(\mathrm{X}_{2}\right)$, Inflasi $\left(\mathrm{X}_{3}\right)$ dan secara bersama-sama mempengaruhi Jumlah Tabungan (LY).

Adapun koefisien determinasi dari Regresi Tabungan sebesar 0.998735. Hal ini hal ini menunjukkan bahwa variabel independent yang terdiri dari pendapatan per kapita $\left(\mathrm{LX}_{1}\right)$, suku 
bunga $\left(\mathrm{X}_{2}\right)$ dan inflasi $\left(\mathrm{X}_{3}\right)$ dalam menjelaskan perubahan variabel dependent/Tabungan sebesar 99,87 $\%$ sedangkan sisanya sebesar $0,13 \%$ dijelaskan oleh variabel lain yang tidak dimasukkan dalam model estimasi.

Hasil penelitian uji heterokedastisitas dilakukan dengan menggunakan metode uji white. Dari hasil penelitian tersebut dapat disimpulkan bahwa Probability $(0.163519)>0,05$, artinya tidak terjadi heterokedastisitas.

Hasil pengolahan uji autokorelasi diperoleh nilai statistik Durbin-Watson $(\mathrm{DW})=1.538988$ pada tingkat kekeliruan $1 \%$ untuk jumlah variabel bebas $(\mathrm{k}-1)=3$ dan jumlah pengamatan $(\mathrm{n})=13$ diperoleh batas bawah nilai tabel $\mathrm{dl}=$ 0,499 dan batas atasnya $\mathrm{du}=1,526$ dengan nilai 4-du : 2,474 dan nilai 4dl :3,501. Nilai Durbin-Watson model regresi (1.538988) berada diantara du=1,526 dan 4-du $=2,474$ maka berada di tidak terjadi autokorelasi. Dengan demikian dapat disimpulkan bahwa hasil regresi variabel Pendapatan per kapita, suku bungan, inflasi terhadap Tabungan tidak terjadi autokorelasi atau $\rho=0$.

Dengan membandingkan $\mathrm{R}^{2}$ dari regresi Tabungan dan regresi anatar variabel bebas maka doperoleh hasil adalah $\mathrm{R}_{1}^{2}(0,9987)$ $>\mathrm{R}_{11}^{2}(0.7479), \mathrm{R}_{12}^{2}$ (0.9359), $\mathrm{R}_{13}^{2}$ $(0,8876)$ sehingga dapat disimpulkan bahwa dalam model regresi diatas tidak terjadi multikolinearitas.

Hasil dari regresi menunujukkan pendapatan per kapita mempunyai pengaruh positif terhadap variabel Tabungan, Giro, Deposito dan Dana Pihak Katiga, hal ini sesuai teori Keynes, yang menyatakan bahwa tabungan merupakan fungsi dari pendapatan. Semakin tinggi pendapatan yang diterima oleh masyarakat maka akan semakin tinggi pula tabungan yang dilakukan oleh sektor Rumah tangga. Jadi pendapatan adalah faktor penentu yang utama masyarakat menyimpan dananya di bank, pada saat ini banyak pilihan produk Dana Pihak Ketiga yang ditawarkan oleh Bank kepada masyarakat, jadi masyarakat dapat memilih produk yang sesuai dengan kebutuhannya 
apakah untuk berjaga-jaga, Transaksi maupun untuk berinvestasi.

$\begin{array}{rrr} & \text { Pengaruh positif Variabel } \\ \text { suku bunga terhadap variabel }\end{array}$ dependent yang terdiri dari Tabungan, Giro, Deposito dan Dana Pihak Ketiga sesuai dengan teori Klasik yang menyatakan tabungan fungsi dari tingkat suku bunga. Pada tingkat suku bunga yang tinggi keinginan masyarakat untuk melakukan saving akan meningkat sehingga masyarakat mengurangi konsumsinya yang akan digunakan untuk menambah tabungannya dibank hal ini dimaksudkan untuk mendapatkan pendapatan dari bunga yang akan digunakan pada masa mendatang.

Pengaruh yang berbeda ditunjukkan oleh variabel inflasi dimana inflasi mempunyai pengaruh negatif terhadap variabel dependent yanng terdiri dari Tabungan, Giro, Deposito dan Dana Pihak Ketiga. Pada tingkat inflasi yang tinggi dimana harga-harga dipasar mengalami kenaikan secara bersamasama maka pendapatan masyarakat akan berkurang sehingga dana yang akan digunakan untuk melakukan saving habis digunakan untuk membiayai konsumsinya bahkan masyarakat akan cenderung menarik simpanan untuk menutupi kekurangan konsumsinya.

\section{KESIMPULAN}

Pada dasarnya Dana Pihak Ketiga yang terdiri dari Tabungan, Giro dan Deposito memiliki karakteristik yang berbeda satu dengan yang lainnya sehingga respon yang ditunjukkan oleh variabel dependent terhadap perubahan variabel makro yang terdiri dari Pendapatan per Kapita, suku bunga dan Inflasi akan berbeda pula. Respon variabel independent terhadap variabel dependent tersebut adalah sebagai berikut: pertama, Variabel pendapatan per kapita. Variabel pendapatan per kapita memiliki respon yang sama pada masing regresi hal ini disebabkan karena pendapatan merupakan faktor penentu yang utama masyarakat melakukan saving baik untuk berjaga-jaga, transaksi maupun untuk investasi hal ini ditunjukkan oleh besarnya probabilitas yang ditunjukkan variabel pendapatan per 
kapita $\left(\mathrm{LX}_{1}\right)$ pada masing regresi sebesar 0,0000.

Kedua, Variabel suku bunga. Reaksi yang ditunjukkan oleh variabel suku bunga memiliki respon yang berbeda-beda pada tiap regresi. Respon tertinggi ditunjukkan pada regresi Deposito $\left(\mathrm{LY}_{3}\right)$ dimana variabel suku bunga memiliki probabilitas sebesar 0,0012 . Sedangkan pada regresi Tabungan dan Giro variabel suku bunga memiliki probabilitas masing-masing sebesar 0,0296 dan 0,0496.

Tingginya respon variabel suku bunga pada regresi Deposito menunjukkan karakteristik Deposito dimana Deposito merupakan sarana investasi yaitu bank akan memberikan suku bunga yang tinggi pada Deposan sehingga jumlah Dana dalam simpanan Deposito sangat tergantung oleh besarnya suku bunga yang diberikan oleh bank. Pada tingkat suku bunga yang tinggi maka jumlah simpanan Deposito akan meningkat dan sebailknya ketika suku bunga mengalami penurunan maka jumlah dana dalam simpanan Deposito akan mengalami penurunan.
Reaksi berbeda ditunjukkan oleh variabel suku bunga pada regresi tabungan. Pada regresi Tabungan, variabel suku bunga masih singnifikan namun tidak sebesar yang ditunjukkan pada regresi Deposito. Perbedaan reeaksi yang ditunjukkan oleh variabel suku bunga pada regresi Tabungan disebabkan karena tujuan nasabah menyimpan dananya adalah untuk beraga-jaga yang akan ditarik apabila dibutuhkan. Dalam kasus ini nasabah tidak mengejar pendapatan yang dari suku bunga sehingga wajar apabila probabilitas variabel suku bunga pada regresi Tabungan lebih kecil daripada rgresi Deposito.

Pada simpanan giro variabel suku bunga memiliki probabilitas yang paling rendah, hal ini disebabkan tujuan girant menyimpan dana pada Bank adalah mendukung kelancaran transaksi bisnis sehingga ketiga variabel suku bunga mengalami perubahan, simpanan Giro tidak telalu merespon.

Simpanan Giro lebih terpengaruh oleh adanya aktifitas ekonomi yang sedang terjadi, semakin maju perekonomian 
masyarakat disuatu daerah sarana pembayaran non tunai akan semakin deperlukan dimana pada masyarakat moderen menutut adanya kemudahan disegala hal termasuk adanya kemudahan dalam hal pembayaran, Sehingga apabila bank ingin meningkatkan jumlah simpanan giro bank hanya perlu memberikan beberapa kemudahan yang dapat menunjang kalancaran bisnis Girant.

Ketiga, Variabel inflasi. Perubahan Variabel inflasi direspon berbeda-beda oleh masing-masing Dana Pihak Ketiga, dimana respon tertinggi ditunjukkna pada Rgresi Tabungan hal ini ditunjukkan oleh probabalititas variabel inflasi pada regresi Tabungan sebesar 0,0024 sedangkan pada regresi Giro dan Deposito masing-masing sebesar 0,0115 dan 0,0465 .

Tabungan memiliki respon yang paling tinggi terhadap variabel inflasi hal ini ditunjukkan probabilitas inflasi pada regresi Tabungan sebesar 0,0024. Tingginya respon Tabungan terhadap perubahan variabel inflasi disebabkan oleh tujuan nasabah adalah untuk beragajaga sehingga pada tingkat inflasi dimana harga barang dan jasa dipasar menglami kenaikan secara serentak, maka nasabah akan lebih memilih untuk menggunakan dana dalam Tabungan untuk memenuhi kekurangan konsumsi dibandingkan harus menyimpan dananya dibank dan memperoleh tingkat bunga yang lebih rendah dibandingkan kanaikan harga barang dan jasa di pasar.

Sedangkan Giro memiliki respon yang lebih rendah terhadap perubahan variabel inflasi, hal ini disebabkan simpanan Giro ditujukan untuk menunjang kelancaran bisinis sehingga selama inflasi tidak mengganggu aktifitas ekonomi atau bisnis maka hal ini tidak telalu mempengaruhi jumlah Simpanan Giro, penurunan jumlah Dana yang terjadi pada simpanan Giro tidak setajam yang terjadi pada Simpanan Tabungan.

Perubahan variabel inflasi direspon berbeda oleh Deposito, dimana pada regresi Deposito variabel inflasi memiliki probabilitas sebesar 0,0465 hal ini menujukkan bahwa depposito menunjukkan respon yang lebih rendah dibandingkan Tabungan dan Giro. 
Rendahnya respon deposito terhadap perubahan inflasi disebabkan deposito merupakan salah satu sarana investasi masyarakat dimana pada tingkat inflasi yang tinggi pemerintah lebih memilih menstabilkan inflasi dengan cara menaikkan suku bunga Sertifikat Bank Indonesia sehingga bank berusaha untuk menghimpun dana masyarakat dengan cara menaikkan suku bunga simpan.

\section{DAFTAR PUSTAKA}

Badan Pusat Statistik, Statistik

Daerah Provinsi Jawa Timur (online)

http://www.bps.go.id/epub/2012/stda2012/index html, Diakses 11 April 2013

Bank Indonesia, Kajian Ekonomi Regional Provinsi Jawa Timur (online) http://www.bi.go.id/web/id/P ublikasi/Ekonomi_Regional/ KER/Jatim/ker_jatim_tw410. html, Diakses 11 April 2013

Fatmawati, Dwi, 2007, Analisis faktor-faktor yang mempengaruhi penghimpunan dana masyarakat pada Bank Umum di wilayah Jawa Timur, Skripsi UMM

Gujarati, Damodar, 2012, DasarDasar Ekonometrika, Edisi kelima, Salemba Empat, Jakarta

Ismail, 2010, Manajemen Perbankan: Dari Teori Menuju Aplikasi, Prenada Media, Jakarta.

Kasmir, 2002, Bank dan Lembaga Keuangan Lainnya; edisi keenam, PT. Raja Grafindo Persada, Jakarta.

Kuncoro, Mudrajat \& Suhardjono, 2002, Manajemen Perbankan Teori dan Aplikasi, Yogyakarta:BPFE, Yogyakarta

Nasution, Mulia 1998, Ekonomi Moneter Uang dan Bank, Djambatan, Jakarta.

Nopirin, 1992, Ekonomi Moneter Edisi, Keempat. BPFEYogyakarta, Yogyakarta.

Republik Indonesia, 1998, UndangUndang Perbankan Nomor 10/1998 Tentang Perubahan Undang-Undang Nomor 7 Tahun1992 Tentang Perbankan

Sidabuntar, Neny 2007, Analisis Faktor-Faktor Yang Mempengaruhi Jumlah Simpanan Masyarakat pada Bank-Bank Umum di Pemantang Siantar/Simalungun, Skripsi Universitas Sumatera Utara

Sukirno, Sadono, 2002, Pengantar Teori Makroekonomi, edisi 
dua belas, PT. Raja Grafindo Persada, Jakarta

Waluyo, Dwi Eko, 2006, Ekonomika Makro, edisi Revisi, UMM Press, Malang
Winarno, Wing Wahyu, 2007, Analisis Ekonometrika dan Statistika dengan Eviews, UPP STIM YKPN, Yogyakarta 